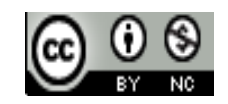

Jurnal Pendidikan Matematika Indonesia is licensed under

A Creative Commons Attribution-Non Commercial 4.0 International License

\title{
Pengaruh Model Pembelajaran Realistic Mathematics Education (RME) Terhadap Kemampuan Penalaran Matematis Siswa Pada Materi Lingkaran Kelas VIII
}

\author{
Desi Gusnarsi ${ }^{1)}$, Citra Utami $^{2)}$, Rika Wahyuni ${ }^{3)}$ \\ 1) Program Studi Pendidikan Matematika STKIP Singkawang \\ E-mail:desigusnarsi@yahoo.com \\ 2) Program Studi Pendidikan Matematika STKIP Singkawang \\ E-mail: citrautami1990@gmail.com \\ 3) Program Studi Pendidikan Matematika STKIP Singkawang \\ E-mail: rikawahyuni142@gmail.com
}

\begin{abstract}
Abstrak. Penelitian ini bertujuan untuk mengetahui pengaruh model pembelajaran Realistic Mathematics Education (RME) terhadap kemampuan penalaran matematis siswa pada materi lingkaran kelas VIII. Penelitian yang digunakan true experiment design dengan desain pretest-posttest control group design. Populasi penelitian ini adalah semua siswa kelas VIII di SMP Negeri 04 Singkawang. Tehnik pengambilan sampel menggunakan purposive sampling dan terpilih kelas VIII A sebagai kelas eksperimen dan VIII D sebagai kelas kontrol. Tehnik analisis data yang digunakan dalam penelitian ini adalah rumus N-gain dan uji-t (independen) untuk mengetahui perbedaan peningkatan, Effect Size untuk mengetahui pengaruh, persentase aktivitas siswa dan nilai motivasi belajar siswa untuk mengetahui aktivitas siswa dan motivasi belajar siswa. Hasil penelitian menunjukkan (1) terdapat perbedaan peningkatan kemampuan penalaran matematis siswa setelah diberikan model pembelajaran Realistic Mathematics Education (RME) yang dibuktikan dengan nilai $\mathrm{N}$-gain 0,51 kategori sedang pada kelas eksprimen dan 0,25 kategori rendah pada kelas kontrol serta uji-t (independen) diperoleh nilai thitung $=5,67>$ ttabel $=2,00$, (2) terdapat pengaruh model pembelajaran Realistic Mathematics Education (RME) terhadap kemampuan penalaran matematis siswa yang dibuktikan perolehan nilai Effect Size sebesar 1,76 dengan kategori tinggi, (3) terdapat pengaruh model pembelajaran Realistic Mathematics Education (RME) terhadap aktivitas siswa yang dibuktikan dengan perolehan persentase aktivitas 67,4\% dengan kategori aktif, (4) terdapat pengaruh model pembelajaran Realistic Mathematics Education (RME) terhadap motivasi siswa yang dibuktikan dengan nilai rata-rata motivasi belajar siswa keseluruhan sebesar 44,76 dengan kategori tinggi.
\end{abstract}

Kata Kunci: Realistic Mathematics Education (RME), Kemampuan Penalaran Matematis

\section{PENDAHULUAN}

Matematika dikenal sebagai suatu ilmu pengetahuan abstrak, yang karakteristik utamanya adalah pola berfikir yang logis, kritis, sistematis, dan konsisten. Matematika merupakan ilmu dasar yang sangat penting. Oleh karenanya, jumlah jam pelajaran matematika lebih banyak dibandingkan dengan pelajaran lain dan juga matematika diajarkan di semua jenjang pendidikan yaitu mulai jenjang sekolah dasar hingga perguruan tinggi. Matematika juga merupakan mata pelajaran yang paling sering digunakan dalam menyelesaikan mata pelajaran lain. Mengingat pentingnya pembelajaran matematika, guru sebagai motivator dan fasilitator pembelajaran dituntut untuk pandai memilih strategi dan metode pembelajaran yang tepat untuk mengajar.

National Council of Teachers of Mathematics (NCTM) menyatakan bahwa standar-standar matematika haruslah meliputi standar isi dan standar proses. Standar isi tersebut meliputi pemecahan masalah, penalaran dan pembuktian, keterkaitan, komunikasi, dan representasi (Fauziah, 2010). National Council of Teachers of Mathematics (NCTM) pada tahun 2000 juga mengembangkan sejumlah standar pendidikan matematika dengan menekankan bahwa pengajaran matematika satu diantaranya harus dapat memberikan kesempatan kepada siswa untuk menggunakan 


\section{- - - Jurnal Pendidikan Matematika Indonesia \\ Volum 2 Nomor 1 bulan Maret 2017. Page 32-36 \\ p-ISSN: 2477-5967 e-ISSN: 2477-8443}

penalaran sistematik dibanyak bagian matematika yang berbeda (Tung, 2015).

Satu diantara tujuan pembelajaran matematika sekolah menurut Permendiknas Nomor 22 tahun 2006 adalah menggunakan penalaran pada pola dan sifat, melakukan manipulasi matematika dalam membuat generalisasi, menyusun bukti atau menjelaskan gagasan dan pernyataan matematika (Zulfa, 2014). Siswa yang memiliki kemampuan penalaran yang baik akan lebih mudah memahami materi matematika. Sebaliknya siswa yang memiliki kemampuan penalaran yang rendah akan kesulitan dalam memahami materi matematika. Dengan kata lain materi matematika dipahami melalui penalaran dan kemampuan penalaran dilatih dan dipahami melalui matematika. Menyadari pentingnya penalaran matematis dalam pembelajaran matematika, maka pembelajaran matematika perlu direncanakan sedemikian rupa sehingga pada akhir pembelajaran, siswa dapat melakukan penalaran mengenai ide-ide matematis.

Hasil Penelitian menunjukkan bahwa siswa kelas VIII SMP memiliki kekurangan dalam hal kemampuan penalaran matematis, dengan kata lain dapat dikatakan bahwa kemampuan penalaran matematis siswa masih rendah (Wulandari, 2011). Didukung hasil wawancara dengan guru pengampu mata pelajaran matematika SMP Negeri 04 Singkawang, peneliti mendapatkan informasi bahwa siswa cenderung mengalami kesulitan jika dihadapkan pada soalsoal yang membutuhkan penalaran. Hal tersebut menunjukkan bahwa masih lemahnya kemampuan penalaran matematis siswa. Hal ini diperkuat dengan hasil prariset yang dilakukan di SMP Negeri 04 Singkawang. Peneliti memberikan soal yang memuat indikator kemampuan penalaran matematis yaitu (a) Kemampuan menyajikan pernyataan matematika secara lisan, tertulis, gambar dan diagram, (b) Kemampuan mengajukan dugaan, (c) Kemampuan untuk melakukan manipulasi matematika, serta (d) Kemampuan menarik kesimpulan dari pernyataan kepada 27 orang siswa kelas VIII.

Dari hasil prariset dapat diinformasikan juga bahwa hanya 5 orang atau sekitar $19 \%$ yang dapat menjawab pertanyaan (a) dengan hasil yang benar, hanya 12 orang siswa atau sekitar $44 \%$ yang dapat menjawab pertanyaan (b) dengan hasil yang benar, hanya 1 orang siswa atau sekitar 4\% yang dapat menjawab pertanyaan (c) dengan hasil yang benar dan hanya 1 orang siswa atau sekitar $4 \%$ yang dapat menjawab pertanyaan (d) dengan tepat. Berdasarkan hasil prariset tersebut dapat disimpulkan bahwa kemampuan penalaran matematis siswa masih rendah. Berdasarkan observasi yang dilakukan peneliti saat guru mengajar di kelas, peneliti melihat proses pembelajaran masih cenderung berpusat pada guru yang mengakibatkan siswa cenderung pasif dalam proses pembelajaran. Hal tersebut terlihat ketika pembelajaran segala informasi pembelajaran diperoleh dari guru, siswa juga tidak berinisiatif untuk mencari informasi lain, dan hanya satu atau dua siswa yang bertanya. Selanjutnya setelah melakukan wawancara dengan salah satu guru pengampu pelajaran matematika di SMP Negeri 04 Singkawang, peneliti juga mendapatkan informasi bahwa proses pembelajaran cenderung menggunakan model pembelajaran konvensional yang tidak menekankan guru untuk mengaplikasikan materi pembelajaran matematika dalam kehidapan nyata siswa sehingga mengakibatkan siswa kurang termotivasi untuk memahami matematika. Hal tersebut terlihat dari hasil tes siswa yang sering tidak mencapai KKM.

Mengantisipasi hal tersebut, maka model pembelajaran yang sebaiknya diterapkan oleh guru hendaknya adalah model pembelajaran yang memberikan kesempatan siswa untuk melakukan penalaran mengenai ide-ide matematis. Model pembelajaran yang dapat diterapkan oleh guru untuk menciptakan tujuan pembelajaran dan dapat memberikan pengaruh baik terhadap penalaran matematis satu diantaranya adalah model pembelajaran Realistic Mathematics Education (RME). Model pembelajaran Realistic Mathematics Education (RME) menitikberatkan pada pembelajaran matematika yang difokuskan pada kehidupan sehari-hari siswa (kontektual) yang menyajikan hal yang sifatnya nyata untuk diajarkan kepada siswa. Dengan menggunakan model pembelajaran Realistic Mathematics Education (RME) yang memiliki prinsip bahwa mengajarkan matematika harus dimulai dari hal yang bersifat kontekstual, siswa akan lebih memahami materi matematika sehingga siswa tidak akan mengalami kesulitan memahami materi matematika yang bersifat abstrak. Model pembelajaran Realistic Mathematics Education (RME) memiliki beberapa keunggulan diantaranya siswa membangun sendiri pengetahuannya, Suasana dalam proses pembelajaran menjadi menyenangkan, Memupuk kerjasama kelompok, serta pendidikan budi pekerti.

Dari beberapa penelitian tentang Realistic Mathematics Education (RME) memberikan hasil yang positif terhadap pembelajaran matematika seperti penelitian yang dilakukan oleh Sa'adah (2010) yang menyatakan bahwa pembelajaran matematika dengan Pembelajaran Matematika Realistik Indonesia dapat meningkatkan kemampuan penalaran matematik siswa kelas VIII. Selanjutnya penelitian yang menyatakan bahwa pembelajaran dengan menggunakan Realistic Mathematics Education (RME), siswa menunjukan kemajuan dalam kinerja mereka dalam mengerjakan tes dan kemampuan pemahaman konsep siswa (Widjaja, 2003) yang.

Lingkaran adalah materi dalam mata pelajaran matematika SMP yang terdapat pada kelas VIII. Lingkaran merupakan satu diantara materi yang diujikan dalam setiap pelaksanaan Ujian Nasional (UN) jenjang SMP. Disamping itu, lingkaran merupakan materi dasar yang berkaitan dengan materi matematika lainnya yang akan dipelajari pada jenjang berikutnya. Lingkaran juga berkaitan dengan kehidupan sehari-hari, misalnya dalam bentuk soal cerita seperti menghitung sebuah roda. Namun kebanyakan siswa mengalami kesulitan dalam menyelesaikan soal dalam bentuk soal cerita. Hal tersebut terjadi karena dalam menyelesaikan soal cerita memerlukan proses bernalar. Akan tetapi kemampuan bernalar siswa masih rendah.

Berdasarkan data yang dikumpulkan dari hasil ulangan harian pada materi lingkaran pada tahun sebelumnya peneliti mendapatkan informasi bahwa hanya sekitar $35 \%$ siswa 
yang sudah mencapai KKM dan sekitar 65\% siswa yang belum mencapai KKM. Hal ini mengindikasikan siswa mengalami kesulitan pada materi lingkaran tersebut. Dalam penelitian ini lingkaran yang akan dipelajari adalah hubungan antara sudut pusat, panjang busur, dan luas juring. Dari pemaparan latar belakang tersebut maka peneliti tertarik untuk melakukan penelitian dengan judul Pengaruh Model Pembelajaran Realistic Mathematics Education (RME) Terhadap Kemampuan Penalaran Matematis Siswa Pada Materi Lingkaran Kelas VIII.

Berdasarkan latar belakang tersebut didapatkan rumusan masalah umum dalam penelitian ini adalah Bagaimana pengaruh model pembelajaran Realistic Mathematics Education (RME) terhadap kemampuan penalaran matematis siswa pada materi lingkaran kelas VIII SMP Negeri 04 Singkawang Tahun Ajaran 2015/2016?. Dari rumusan masalah di atas, adapun sub-sub masalah yang dapat dikembangkan dalam penelitian ini adalah (1) Apakah terdapat perbedaan peningkatan kemampuan penalaran matematis siswa dengan menggunakan model pembelajaran Realistic Mathematics Education (RME) dan model pembelajaran konvensional pada materi lingkaran kelas VIII SMP Negeri 04 Singkawang Tahun Ajaran 2015/2016? (2) Apakah terdapat pengaruh model pembelajaran Realistic Mathematics Education (RME) terhadap kemampuan penalaran matematis siswa pada materi lingkaran kelas VIII SMP Negeri 04 Singkawang Tahun Ajaran 2015/2016 ? (3) Apakah terdapat pengaruh model pembelajaran Realistic Mathematics Education (RME) terhadap aktivitas siswa saat pembelajaran pada materi lingkaran kelas VIII SMP Negeri 04 Singkawang Tahun Ajaran 2015/2016 ? (4) Apakah terdapat pengaruh model pembelajaran Realistic Mathematics Education (RME) terhadap motivasi siswa saat pembelajaran pada materi lingkaran kelas VIII SMP Negeri 04 Singkawang Tahun Ajaran 2015/2016?

\section{Metode Penelitian}

Jenis penelitian yang diterapkan merupakan penelitian kuantitatif metode eksperimen. Desain penelitian yang digunakan yaitu True Experimental Design dengan bentuk Pretest-Posttest Control Group Design. Populasi dalam penelitian ini adalah seluruh siswa kelas VIII SMP Negeri 04 Singkawang tahun ajaran 2015/2016 yang tersebar dalam 8 kelas yaitu VIII A, VIII B, VIII C, VIII D, VIII E, VIII F, VIII G, dan VIII H. Pengambilan sampel dilakukan dengan teknik Sampling Purposive, sehingga terpilih kelas VIII A sebagai kelas eksperimen dan kelas VIII D sebagai kelas kontrol.

Tehnik pengumpulan data yang digunakan dalam penelitian ini adaah sebagai berikut: (a) Teknik Pengukuran, yang berbentuk pretest dan posttest. (b) Teknik observasi langsung, digunakan untuk mengetahui aktivitas siswa selama pembelajaran berlangsung. (c) Teknik komunikasi tidak langsung, yang digunakan untuk mengetahui motivasi belajar siswa dengan menggunakan model pembelajaran Realistic Mathematics Education (RME).

Instrumen pengumpul data dalam penelitian ini yaitu sebagai berikut: (a) Tes kemampuan penalaran matematis dalam bentuk essay yang terdiri dari dua butir soal. (b) Lembar pengamatan aktivitas siswa yang diisi oleh tiga obsever dan (3) Angket motivasi belajar siswa yang terdiri dari 12 butir pernyataan. Sebelum semua instrumen penelitian tersebut digunakan, maka terlebih dahulu instrumen diuji cobakan ke sekolah lain yaitu SMP Negeri 08 Singkawang untuk mengetahui kevaliditas, reliabilitas, daya pembeda dan indeks kesukarannya.

Kemudian teknik analisis data yang digunakan dalam penelitian ini adalah sebagai berikut. (1) Untuk menjawab sub masalah 1 yaitu mengetahui perbedaan peningkatan kemampuan penalaran matematis siswa dengan menggunakan model pembelajaran Realistic Mathematics Education (RME) dan model pembelajaran konvensional pada materi lingkaran kelas VIII SMP Negeri 04 Singkawang maka digunakan rumus N-gain dan uji-t. (2) Untuk menjawab sub masalah 2 yaitu mengetahui pengaruh model pembelajaran Realistic Mathematics Education (RME) terhadap kemampuan penalaran matematis siswa pada materi lingkaran kelas VIII SMP Negeri 04 Singkawang, maka dilakukan pehitungan dengan rumus effect size. (3) Untuk menjawab sub masalah 3 yaitu mengetahui aktivitas belajar siswa maka digunakan rumus presentase aktivitas siswa. (4) untuk menjawab sub masalah 4 yaitu untuk mengetahui motivasi belajar siswa digunakan rumus presentase motivasi belajar siswa.

\section{HASIL DAN PEMBAHASAN}

Adapun hasil penelitian yang akan dipaparkan adalah kemampuan penalaran matematis siswa pada materi lingkaran, aktivitas belajar siswa selama pembelajaran dengan menggunakan model pembelajaran Realistic Mathematics Education (RME) dan motivasi belajar siswa terhadap pembelajaran dengan menggunakan model pembelajaran Realistic Mathematics Education (RME) untuk hasil tes kemampuan penalaran matematis siswa pada penelitian ini diperoleh dari hasil jawaban pretest dan posttest siswa baik di kelas eksperimen dan kelas kontrol. Adapun data hasil perhitungan nilai pretest dan posttest siswa pada kelas eksperimen dan kelas kontrol dapat dilihat di Tabel 1 sebagai berikut.

TABEL 1

ReKapitulasi Uji $N$-Gain Kemampuan Penalaran Matematis Siswa KELAS EKSPERIMEN DAN KELAS KONTROL

\begin{tabular}{ccccc}
\hline \multirow{2}{*}{ Kelas } & \multicolumn{2}{c}{ Nilai rata-rata } & \multirow{2}{*}{$\boldsymbol{g}$} & \multirow{2}{*}{ Kategori } \\
\cline { 2 - 3 } & Pretest & Posttest & & \\
\hline Eksperimen & 31,6 & 65,3 & 0,51 & Sedang \\
Kontrol & 30,5 & 47,2 & 0,25 & Rendah \\
\hline
\end{tabular}

Dari hasil penelitian yang telah dilaksanakan menunjukkan bahwa pembelajaran matematika dengan menggunakan model pembelajaran Realistic Mathematics Education (RME) pada materi lingkaran dapat meningkatkan kemampuan penalaran matematis siswa. Hal tersebut dapat terlihat dari hasil tes kemampuan penalaran matematis siswa berupa pretest dan posttest yang memuat empat indikator 
kemampuan penalaran matematis yaitu (1) kemampuan menyajikan pernyataan matematika secara lisan, tertulis, gambar dan diagram, (2) kemampuan mengajukan dugaan, (3) kemampuan melakukan manipulasi matematika dan (4) menarik kesimpulan dari pernyataan. Pada kelas eksperimen yang diberikan perlakuan dengan menggunakan model pembelajaran Realistic Mathematics Education (RME), diperoleh hasil pretest yaitu 31,6 meningkat menjadi 65,3 sehingga diperoleh nilai n-gain 0,51 dengan kategori sedang. Sedangkan untuk kelas kontrol yang menggunakan model pembelajaran konvensional, diperoleh hasil pretest yaitu 30,5 meningkat menjadi 47,2 sehingga diperoleh nilai n-gain 0,25 dengan kategori rendah. Hal tersebut menunjukkan peningkatan antara kelas eksperimen dan kelas kontrol berbeda. Oleh sebab itu, dilakukan dilakukan uji homogenitas dan uji normalitas sebagai prasyarat melakukan uji-t. Adapun hasil dari uji normalitas data dapat dilihat pada Tabel II sebagai berikut.

TABEL II

REKAPITULASI UJI NORMALITAS DATA

\begin{tabular}{ccccc}
\hline Kelas & Tes & $\boldsymbol{X}^{2}$ hitung & $\boldsymbol{X}^{2}$ tabel & Keterangan \\
\hline \multirow{2}{*}{ Eksperimen } & Pretest & 6,4665 & 7,815 & Normal \\
& Posttest & 7,6353 & 7,815 & Normal \\
\multirow{2}{*}{ Kontrol } & Pretest & 6,4191 & 7,815 & Normal \\
& Posttest & 4,7933 & 7,815 & Normal \\
\hline
\end{tabular}

Berdasarkan hasil uji normalitas data uji homogenitas dapat dilihat bahwa data berdistribusi normal dan homogen dengan nilai Fhitung $=1,84<$ Ftabel $=1,87$. Selanjutnya dilakukan uji-t dan hasil perhitungan uji-t dapat dilihat pada Tabel III sebagai berikut.

TABEL III

HASIL PERHITUNGAN UJI-T

\begin{tabular}{cc}
\hline thitung & tabel \\
\hline 5,67 & 2,00 \\
\hline
\end{tabular}

Dari hasil perhitungan uji-t diperoleh nilai thitung $>$ ttabel $(5,67>2,00)$ yang berarti terdapat perbedaan peningkatan yang signifikan kemampuan penalaran matematis siswa dengan model pembelajaran Realistic Mathematics Education (RME) dan pembelajaran konvensional. Hasil penelitian ini didukung oleh teori belajar menurut Piaget yang menyatakan bahwa prinsip dasar dari pengembangan pengetahuan seseorang adalah berlangsungnya adaptasi pikiran seseorang kedalam realitas disekitarnya sehingga dapat disimpulkan bahwa pembelajaran menggunakan model pembelajaran Realistic Mathematics Education (RME) dapat meningkatkan kemampuan penalaran matematis siswa.

Kemudian berdasarkan hasil perhitungan menggunakan effect size diperoleh nilai effect size sebesar 1,76 yang menunjukkan bahwa adanya pengaruh model pembelajaran Realistic Mathematics Education (RME) terhadap kemampuan penalaran matematis siswa pada materi lingkaran kelas VIII dengan kriteria tinggi. Selanjutnya untuk aktivitas belajar siswa selama pembelajaran dengan menggunakan model pembelajaran Realistic Mathematics
Education (RME) diperoleh dari hasil lembar pengamatan aktivitas siswa yang diisi oleh tiga orang obsever yang melakukan pengamatan selama proses pembelajaran berlangsung. Adapun data hasil pengamatan aktivitas siswa dapat dilihat pada Tabel IV sebagai berikut.

TABEL IV

ReKapitulasi Hasil Pengamatan AKTIVITAS SISWA

\begin{tabular}{|c|c|c|c|}
\hline Indikator & Rata-rata & Kritera & $\begin{array}{c}\text { Rata-rata } \\
\text { keseluruhan }\end{array}$ \\
\hline $\begin{array}{c}\text { Visual } \\
\text { activities }\end{array}$ & $68,7 \%$ & Aktif & \\
\hline Oral activities & $54,2 \%$ & $\begin{array}{l}\text { Cukup } \\
\text { Aktif }\end{array}$ & $67,6 \%$ \\
\hline $\begin{array}{l}\text { Listening } \\
\text { activities }\end{array}$ & $84,3 \%$ & $\begin{array}{l}\text { Sangat } \\
\text { Aktif }\end{array}$ & Aktif \\
\hline $\begin{array}{c}\text { Writing } \\
\text { activities }\end{array}$ & $63,1 \%$ & Aktif & \\
\hline
\end{tabular}

Berdasarkan hasil pengamatan aktivitas siswa yang telah dilakukan terungkap bahwa model pembelajaran Realistic Mathematics Education (RME) berpengaruh terhadap aktivitas siswa. Hal ini dapat dilihat dari hasil perhitungan data aktivitas siswa pada kelas eksperimen memperoleh rata-rata persentase keseluruhan sebesar $67,6 \%$ dengan kategori aktif.

Hasil penelitian terakhir adalah motivasi belajar seluruh siswa terhadap pembelajaran dengan menggunakan model pembelajaran Realistic Mathematics Education (RME) diperoleh dari hasil angket motivasi belajar siswa yang terdiri dari 12 pernyataan dan siswa dapat menjawab berdasarkan apa yang mereka rasakan. Adapun hasil angket motivasi belajar siswa dapat dilihat pada Tabel V sebagai berikut.

TABEL V

REKAPITULASI ANGKET MOTIVASI BELAJAR SISWA

\begin{tabular}{ccc}
\hline Jumlah & Rata-rata & Keterangan \\
\hline 1298 & 44,76 & Tinggi \\
\hline
\end{tabular}

Berdasarkan hasil angket motivasi belajar siswa menunjukkan bahwa model pembelajaran Realistic Mathematics Education (RME) berpengaruh terhadap motivasi belajar siswa. Hal tersebut dapat dilihat dari hasil angket motivasi belajar siswa secara keseluruhan diperoleh rata-rata angket motivasi belajar siswa keseluruhan sebesar 44,76. Sesuai dengan kriteria penilaian angket motivasi bahwa 44,76 terletak diantara 40,81 $<\mathrm{x}^{-} \leqslant 50,40$ yang berarti motivasi belajar siswa dikatagorikan tinggi sehingga dapat dikatakan bahwa model pembelajaran Realistic Mathematics Education (RME) berpengaruh terhadap motivasi belajar siswa.

Hal ini sejalan dengan kelebihan dari model pembelajaran Realistic Mathematics Education (RME) yang dikemukakan Asmin (dalam Ningtias,2014:18) yang menyatakan bahwa suasana dalam proses pembelajaran dengan Realistic Mathematics Education (RME) menjadi menyenangkan, karena dengan menggunakan masalah 
kontekstual sehingga meningkatkan motivasi siswa dan ketertarikan siswa dalam belajar matematika.

\section{KESIMPULAN DAN SARAN}

Kesimpulan

Dengan memperhatikan hasil penelitian dan pembahasan yang telah peneliti paparkan, maka secara umum dapat disimpulkan bahwa model pembelajaran Realistic Mathematics Education (RME) berpengaruh terhadap kemampuan penalaran matematis siswa pada materi lingkaran kelas VIII. Sesuai dengan rumusan sub-sub masalah penelitian, secara khusus dapat disimpulkan beberapa hal sebagai berikut:

1. Terdapat perbedaan peningkatan kemampuan penalaran matematis siswa dengan menggunakan model pembelajaran Realistic Mathematics Education (RME) dan model pembelajaran konvensional pada materi lingkaran kelas VIII. Hal ini dibuktikan dengan uji Ngain diperoleh nilai $\mathrm{N}$-gain 0,51 kategori sedang pada kelas eksprimen dan 0,25 kategori rendah pada kelas kontrol. Dan dengan uji-t (independen) dengan membandingkan nilai thitung dan ttabel pada hasil posttest kemudian diperoleh nilai thitung $>$ ttabel $(5,67>$ 2,00).

2. Terdapat pengaruh model pembelajaran Realistic Mathematics Education (RME) terhadap kemampuan penalaran matematis siswa pada materi lingkaran kelas VIII. Hal ini dibuktikan dengan uji Effect Size diperoleh nilai Effect Size sebesar 1,76 dengan kategori tinggi.

3. Terdapat pengaruh model pembelajaran Realistic Mathematics Education (RME) terhadap aktivitas siswa saat pembelajaran pada materi lingkaran kelas VIII. Hal ini dibuktikan dengan perhitungan persentase aktifitas siswa diperoleh persentase $67,4 \%$ dengan kategori aktif.

4. Terdapat pengaruh model pembelajaran Realistic Mathematics Education (RME) terhadap motivasi belajar siswa saat pembelajaran pada materi lingkaran kelas VIII. Hal ini dibuktikan dengan nilai rata-rata motivasi belajar siswa keseluruhan sebesar 44,76 dengan kategori tinggi.

Saran

Peneliti memberikan beberapa saran sebagai berikut:

1. Model pembelajaran Realistic Mathematics Education (RME) dapat menjadi satu diantara alternatif dalam pembelajaran matematika untuk meningkatkan kemampuan penalaran matematis siswa.
2. Dalam penyampaian materi pelajaran matematika pada pokok bahasan lingkaran, guru perlu mencoba pembelajaran dengan menggunakan model pembelajaran Realistic Mathematics Education (RME).

3. Guru harus lebih kreatif dalam menyajikan pembelajaran matematika dengan menggunakan model pembelajaran Realistic Mathematics Education (RME) agar pembelajaran matematika lebih menarik dan tidak menimbulkan kebosanan bagi siswa.

4. Guru sebaiknya memberikan arahan yang jelas kepada siswa agar siswa memahami jalannya pembelajaran dengan menggunakan model pembelajaran Realistic Mathematics Education (RME) dan memantau aktivitas siswa selama pembelajaran berlangsung.

\section{UCAPAN TERIMA KASIH}

Penulis mengucapkan terima kasih kepada dosen pembimbing yaitu Citra Utami, M.Pd. selaku dosen pembimbing I dan Rika Wahyuni, S.Si., M.Pd. selaku dosen pembimbing II yang telah membimbing dan mengarahkan penulis dalam menyelesaikan jurnal ini. Kemudian penulis juga mengucapkan terima kasih kepada STKIP Singkawang yang telah menfasilitasi penulis dalam menyelesaikan jurnal ini.

\section{DAFTAR PUSTAKA}

Fauziah, A. (2010)."Peningkatan Kemampuan Pemahaman dan Pemecahan Masalah Matematik Siswa SMP Melalui Strategi REACT". Forum Pendidikan. Vol.30 No. 1

Tung, Khoe Yau .(2015). Pembelajaran dan Perkembangan Belajar. Jakarta: PT Indeks.

Wulandari, E. (2011). "Meningkatkan Kemampuan Penalaran Matematis Siswa Melalui Pendekatan Problem Posing Di Kelas VIII A SMP Negeri 2 Yogyakarta". Skripsi. Yogyakarta : Fakultas Matematika dan Ilmu Pengetahuan Alam, Universitas Negeri Yogyakarta.

Zulfa, F.S. (2014) "Pengaruh Penerapan Model Penemuan Terbimbing Terhadap Kemampuan Penalaran Matematis Siswa Kelas XI IPA SMAN 1 Padang Panjang”. Jurnal Pendidikan Matematika. Vol.3 No.3. 